\title{
Pengaruh Pemijatan Perineum pada Primigravida terhadap Kejadian Ruptur Perineum saat Persalinan di Bidan Praktek Mandiri di Kota Bengkulu Tahun 2014
}

\author{
Wewet Savitri ${ }^{1}$, Ermawati ${ }^{2}$, Elda Yusefni ${ }^{3}$
}

\begin{abstract}
Abstrak
Ruptur perineum merupakan salah satu komplikasi persalinan kala II yang dapat menyebabkan disfungsi organ reproduksi wanita, perdarahan dan laserasi. Sebanyak $85 \%$ wanita melahirkan pervaginam dapat mengalami ruptur perineum. Salah satu cara mengurangi ruptur perineum adalah dengan melakukan pemijatan perineum untuk meningkatkan kesehatan, aliran darah dan elastisitas perineum. Tujuan penelitian ini adalah untuk menentukan pengaruh pemijatan perineum pada primigravida terhadap kejadian ruptur perineum saat persalinan di Bidan Praktek Mandiri di Kota Bengkulu Tahun 2014. Penelitian ini merupakan penelitian quasi eksperimen dengan metode post test only control group design. Penelitian dilakukan di Bidan Praktek Mandiri (BPM) kota Bengkulu dengan subjek 28 orang primigravida usia kehamilan 36 minggu yang terdiri dari 14 orang kelompok intervensi dan 14 orang kelompok kontrol. Penelitian dilakukan dari 10 Maret 2014 hingga 10 Mei 2014, kemudian data dianalisis dengan uji Chi Square. Kejadian ruptur perineum pada kelompok intervensi setelah dilakukan pemijatan perineum hanya $21,4 \%$ sementara pada kelompok kontrol $71,4 \%$. Hasil penelitian membuktikan ada pengaruh pemijatan perineum pada primigravida terhadap kejadian ruptur perineum $(p<0,05)$. Penelitian ini menyimpulkan bahwa pemijatan perineum pada primigravida berpengaruh terhadap kejadian ruptur perineum pada saat persalinan.
\end{abstract}

Kata kunci: pemijatan perineum, primigravida, ruptur perineum

\begin{abstract}
Perineal rupture is one of the second stage of labor complications that can lead to dysfunction of the female reproductive organs, bleeding and lacerations. As many as $85 \%$ of women give birth vaginally may experience rupture of the perineum. A method of reduce perineal rupture is a perineal massage to promote health, blood flow and elasticity of the perineum. The objekctive of this study was to determine the effect of perineal massage on the incidence of perineal rupture in primigravid during childbirth in Independent Practice of Midwifery in the city of Bengkulu year 2014. This study was a quasi-experimental study with the method of post test only control group design. The study was conducted in independent practice of midwifery) in Bengkulu city including subject of 28 primigravida with 36 weeks of gestation consisting of 14 intervention group and 14 control group. The study was done from March 10 th untill may 10th 2014, then the data were analyzed with chi- square test. Perineal rupture in the intervention group after perineal massage performed only $21.4 \%$ while in the control group was $71.4 \%$. this study showed that there was effect of perineal massage on the incidence of perineal rupture of primigravida $(p<0.05)$. This study concludes that perineal massage in primigravida can effected the incidence of perineal rupture at delivery.
\end{abstract}

Keywords: perineal massage, primigravida, perineal rupture

Affiliasi Penulis : 1. Program Studi Magister Kebidanan FK UNAND (Fakultas Kedokteran Universitas Andalas Padang), 2. Obgyn FK UNAND/RSUP Dr.M.Djamil Padang 3. Program Studi Kebidanan Poltekkes Kemenkes Padang
Korespondensi: Wewet Savitri, E-mail: wewet_savitri@yahoo.com, hp: 081367440623 


\section{PENDAHULUAN}

Persalinan adalah proses pengeluaran hasil konsepsi (janin dan plasenta) yang telah cukup bulan atau hampir cukup bulan dan dapat hidup diluar kandungan melalui jalan lahir atau melalui jalan lahir lain dengan bantuan atau tanpa bantuan (kekuatan sendiri). ${ }^{1}$ Proses persalinan dapat dipengaruhi oleh beberapa faktor antara lain fisik/tenaga ibu, jalan lahir, janin, psikologi ibu dan penolong. Faktor jalan lahir mempunyai peranan penting baik sebelum maupun sesudah proses persalinan. ${ }^{2}$

Perineum adalah salah satu jalur yang dilalui pada saat proses persalinan dapat robek ketika melahirkan atau secara sengaja digunting guna melebarkan jalan keluarnya bayi (episiotomi). ${ }^{3}$ Laserasi atau ruptur selama persalinan adalah penyebab perdarahan masa nifas yang nomor dua terbanyak ditemukan. Persalinan pervaginam sering disertai dengan ruptur. Pada beberapa kasus ruptur ini menjadi lebih berat, vagina mengalami laserasi dan perineum sering robek terutama pada primigravida, ruptur dapat terjadi secara spontan selama persalinan pervaginam. Perdarahan masa nifas akut, ruptur yang diabaikan dapat menyebabkan kehilangan darah yang banyak tapi perlahan selama berjam-jam. ${ }^{4}$

Jaringan lunak dan struktur disekitar perineum akan mengalami kerusakan pada setiap persalinan. Kerusakan biasanya lebih nyata pada wanita primipara karena jaringan pada primipara lebih padat dan lebih mudah robek dari pada wanita multipara. ${ }^{5}$ Ruptur Perineum dapat terjadi karena adanya ruptur spontan maupun episiotomi. Perineum yang dilakukan dengan episiotomi itu sendiri harus dilakukan atas indikasi antara lain yaitu bayi besar,perineum kaku, persalinan dengan kelainan letak, persalinan dengan menggunakan alat baik forceps maupun vacum karena apabila episiotomi itu tidak dilakukan atas indikasi di atas, maka menyebabkan peningkatan kejadian dan beratnya kerusakan pada daerah perineum yang lebih berat. Sedangkan luka perineum itu sendiri akan mempunyai dampak tersendiri bagi ibu yaitu gangguan ketidaknyamanan. ${ }^{6}$

Laserasi perineum dipengaruhi oleh beberapa faktor yaitu faktor maternal, faktor janin dan faktor penolong. Faktor maternal meliputi perineum yang kaku dan oedema, primigravida, kesempitan pintu bawah panggul, kelenturan jalan lahir, mengejan terlalu kuat, partus presipitatus, persalinan dengan tindakan seperti ektraksi vakum, ekstraksi forcep, versi ekstraksi dan embriotomi, varikosa pada pelvis maupun jaringan parut pada perineum dan vagina. Faktor janin meliputi janin besar, posisi abnormal seperti oksipitoposterior, presentasi muka, presentasi dahi, presentasi bokong, distosisia bahu dan anomali kongenital seperti hidrosefalus. Faktor penolong meliputi cara memimpin mengejan, cara berkomunikasi dengan ibu, keterampilan menahan perineum pada saat ekspulsi kepala, episiotomi dan posisi meneran. ${ }^{7}$

Pijat perineum adalah salah satu cara untuk meningkatkan kesehatan, aliran darah, elastisitas, dan relaksasi otot-otot dasar panggul. Teknik ini, jika dilatih pada tahap akhir kehamilan (mulai minggu ke-34) sebelum persalinan, juga akan membantu mengenali dan membiasakan diri dengan jaringan yang akan dibuat rileks dan bagian yang akan dilalui oleh bayi. ${ }^{8}$

Tujuan penelitian ini adalah mengetahui pengaruh pemijatan perineum pada primigravida terhadap kejadian ruptur perineum saat persalinan di Bidan Praktek Mandiri di Kota Bengkulu Tahun 2014.

\section{METODE}

Penelitian ini merupakan penelitian eksperimen dengan menggunakan post test only control group design dengan subyek penelitian yang dipilih adalah semua populasi yang memenuhi kriteria inklusi dan eksklusi.

Jumlah sampel dihitung dengan menggunakan rumus uji hipotesis satu sampel tunggal untuk estiminasi proporsi suatu populasi terhadap rerata dua populasi independen. Proporsi kedua kelompok adalah 0,044. Berdasarkan rumus tersebut, diperoleh jumlah sampel sebesar 16 orang, ditambah drop out $10 \%$ menjadi 18 orang. Rumus sampel:

$$
\begin{aligned}
& n=\frac{z \alpha^{2} P Q}{d^{2}} \\
& n=\frac{1.96^{2 \wedge} 0.04^{\wedge} 0.95}{0.10^{2}} \\
& n=16
\end{aligned}
$$


Ket :

$\mathrm{n}$ = besar sampel

$z_{\alpha}=$ tingkat kemaknaan yang dikehendaki $95 \%=1,96$

$\mathrm{P}=$ proporsi rupture perineum pada primigravida (dari pustaka $=0,04$ )

$Q=$ nilai dari 1-p

$\mathrm{d}=$ tingkat ketepatan absolut yang dikehendaki $(0,10)^{9}$

\section{HASIL}

Penelitian telah dilakukan terhadap 28 responden yang memenuhi kriteria inklusi dan ekslusi yang terdiri dari dua kelompok (kelompok A sebanyak 14 responden dan kelompok $B$ sebanyak 14 responden).

Tabel 1. Karakteristik Frekuensi Responden pada Kelompok Intervensi dan Kelompok Kontrol

\begin{tabular}{llllll}
\hline No & Karateristik & $\begin{array}{l}\text { Kelompok } \\
\text { Intervensi }\end{array}$ & \multicolumn{2}{l}{$\begin{array}{l}\text { Kelompok } \\
\text { Kontrol }\end{array}$} \\
\cline { 3 - 6 } & & $\mathbf{n}$ & $\%$ & $\mathbf{n}$ & $\%$ \\
\hline 1 & Umur & & & & \\
& $<20$ & 1 & 7,1 & 4 & 2,6 \\
& $20-35$ & 13 & 92,9 & 10 & 71,4 \\
& Pendidikan & & & & \\
& SMP & 4 & 28,6 & 3 & 21,4 \\
& SMA & 7 & 50,0 & 7 & 50,0 \\
& Diploma & 2 & 14,3 & 4 & 28,6 \\
& Sarjana & 1 & 7,1 & 0 & 0 \\
& Pekerjaan & & & & \\
& IRT & 8 & 57,1 & 7 & 50,0 \\
& PNS & 2 & 14,3 & 2 & 14,3 \\
& Swasta & 4 & 28,6 & 5 & 35,7 \\
\hline \multirow{2}{*}{3} & & & & &
\end{tabular}

Ket :

$\mathrm{n}$ : jumlah responden

$\%$ : persentase nilai jumlah responden

Tabel 1 menunjukkan bahwa berdasarkan karateristik responden pada kelompok intervensi menurut usia primigravida sebagian besar berumur 20-35 tahun sebanyak 13 orang (92,9\%). Berdasarkan tingkat pendidikan separoh ibu hamil berpendidikan SMA sebanyak 7 orang (50,0\%). Berdasarkan pekerjaan separoh ibu hamil adalah ibu rumah tangga sebanyak 8 orang $(57,1 \%)$. Berdasarkan umur primigravida pada kelompok kontrol lebih dari separoh berumur 20-35 tahun sebanyak 10 orang (71,4\%). Berdasarkan tingkat pendidikan separoh ibu hamil adalah SMA sebanyak 7 orang $(50,0 \%)$. Berdasarkan pekerjaan separoh ibu hamil adalah ibu rumah tangga sebanyak 7 orang $(50,0 \%)$.

Tabel 2. Pengaruh Pemijatan Perineum pada Primigravida terhadap Kejadian Ruptur Perineum Saat Persalinan antara Kelompok Intervensi dan Kontrol

\begin{tabular}{llrrrrr}
\hline $\begin{array}{l}\text { Pemijatan } \\
\text { perineum }\end{array}$ & \multicolumn{3}{c}{ Ruptur Perineum } & \multicolumn{2}{c}{ Total } \\
& \multicolumn{2}{c}{ Tdk ruptur } & \multicolumn{2}{c}{ Ruptur } & \multicolumn{2}{c}{ Jumlah } \\
& $\mathrm{f}$ & $\%$ & $\mathrm{f}$ & $\%$ & $\mathrm{f}$ & $\%$ \\
\hline & & & & & & \\
Intervensi & 11 & 78,6 & 3 & 21,4 & 14 & 100 \\
Kontrol & 4 & 28,6 & 10 & 71,4 & 14 & 100 \\
jumlah & 15 & & 13 & & 28 & \\
\hline Nilai $\mathrm{p}=0,02$ & & & & & &
\end{tabular}

Nilai $p=0,02$

Tabel 2 menunjukan bahwa kejadian ruptur perineum lebih banyak pada kelompok kontrol 10 orang $(71,4 \%)$ yang tidak dilakukan pemijatan perineum dibandingkan pada kelompok intervensi 3 orang $(21,4 \%)$ yang dilakukan pemijatan perineum. Setelah dilakukan uji Chi-Square diperoleh nilai $p=$ $0,02(<0,05)$ maka secara statistik menunjukan ada pengaruh pemijatan perineum pada primigravida terhadap kejadian ruptur perineum pada saat persalinan antara kelompok Intervensi dan kelompok kontrol.

\section{PEMBAHASAN}

Berdasarkan penelitian ini maka diperoleh karateristik primigravida berdasarkan umur pada kelompok intervensi dan kelompok kontrol sebagian besar berumur 20-35 tahun. Pada usia reproduktif (20 -35 tahun) pada saat ini respon ibu untuk menerima pengertian tentang pemijatan perineum, manfaat dan cara pemijatan perineum lebih efektif dan dapat mempelajarinya.

Menurut Hurlock, bahwa usia reproduktif (2035 tahun) terjadi kesiapan respon maksimal baik dalam menyesuaikan hal-hal tertentu dan sedikit demi sedikit menurun seiring dengan bertambah umur. Selain itu pada usia reproduktif mereka lebih terbuka terhadap orang lain dan biasanya mereka akan saling bertukar pengalaman tentang hal yang sama yang pernah mereka alami. ${ }^{10}$ 
Reproduksi sehat adalah usia aman untuk kehamilan dan persalinan yaitu pada usia 20-35 tahun. Komplikasi pada wanita hamil dan melahirkan pada usia di bawah 20 tahun ternyata 2-5 kali lebih tinggi dari pada usia 20-35 tahun. Komplikasi maternal kembali meningkat sesudah usia 35 tahun keatas. ${ }^{11}$

Menurut Beckmann dan Garrett, pijat perineum pada saat antenatal dimulai dari kehamilan $35 \mathrm{mg}$ akan mengurangi kemungkinan trauma perineum yang memerlukan jahitan. Pijat perineum juga bermanfaat untuk menghilangkan nyeri perineum setelah persalinan. ${ }^{12}$

Hasil penelitian ini sama dengan yang dilakukan oleh Shipman $d k k$ yaitu pijat perineum dalam periode antenatal dapat membantu mengurangi tindakan untuk episiotomi dan resiko laserasi kedua dan ketiga. ${ }^{13}$ Menurut Johanson, dokter kandungan dari Nort Staffordshire Maternity Hospital, Inggris, mencatat lbu yang rajin melakukan pemijatan perineum sejak tiga bulan sebelum persalinan, terbukti hampir tidak ada yang memerlukan tindakan episiotomi. Kalaupun terjadi robekan perineum secara alamiah, maka luka akan pulih dengan cepat. ${ }^{14}$

Karacam et al juga mendapatkan bahwa pemijatan perineum dapat menurunkan jumlah ruptur perineum dan tindakan untuk episiotomi pada saat persalinan. ${ }^{15}$

Jones dan Marsden mengemukakan bahwa penerapan pemijatan perineum pada masa kehamilan harus sesuai dengan petunjuk dan cara pemijatan yang telah ada. ${ }^{16}$

Aprilia mengemukakan bahwa minimalnya robekan perineum dapat terjadi karena pada saat ibu dilakukan pemijatan perineum jaringan pada perineum menjadi rileks sehingga dapat menyebabkan peningkatan elastisitas jalan lahir yang dapat mempermudah proses melahirkan serta mengurangi kejadian robekan perineum. ${ }^{17}$

Chapman mengemukan bahwa pemijatan perineum juga dapat sebagai mekanisme koping bagi ibu yaitu untuk menghilangkan rasa takut dan cemas saat persalinan karena selama kehamilan jaringan disekitar perineum sudah dilakukan pemijatan perineum sehingga jaringan disekitar perineum menjadi elastis. ${ }^{18}$

Menurut Danuatmaja, bahwa pemijatan perineum yang dilakukan sejak bulan-bulan terakhir kehamilan menyiapkan jaringan kulit perineum lebih elastis sehingga lebih mudah meregang. Selain itu meningkatkan elastisitas vagina untuk membuka, sekaligus melatih ibu untuk aktif mengendurkan perineum ketika ia merasakan tekanan saat kepala bayi lahir. Ini dapat mengurangi robekan perineum, mengurangi pemakaian episiotomi, dan mengurangi penggunaan alat bantu persalinan lainnya. ${ }^{19}$ Banyak ibu merasakan perubahan daya regang daerah perineumnya setelah satu atau dua minggu pemijatan. Ketidakadekuatan elastisitas perineum merupakan faktor maternal yang sangat berpengaruh terhadap terjadinya ruptur perineum maupun tindakan episiotomi. $^{20}$

Chomaria mengatakan bahwa episiotomi adalah suatu prosedur dengan memberikan perlukaan pada perineum ketika seorang ibu akan melahirkan bayinya untuk mempermudah pengeluaraan bayi tanpa robekan yang tidak beraturan. Hal inilah yang banyak dicemaskan ibu hamil menjelang persalinannya. Sebenarnya hal ini bisa terkurangi resikonya dengan cara melatih elastisitas perineum sehingga tidak perlu episiotomi oleh tenaga medis yang membantu ibu ketika melahirkan bayinya. Ibu bisa memijat daerah perineum dengan cara yaitu berikan pelumas pada jari, letakan ibu jari pada perineum, tekan dengan lembut dan perlahan perineum kearah rectum (anus), kearah samping dan lakukan hal ini dengan baik dan teratur. ${ }^{21}$

Jaringan ikat pada perineum menyatukan jaringan lain yang berbeda melaluli akumulasi protein dan zat yg mirip gel yang disekresikan dari fibroblast kedalam ruangan yang mengelilingi sel. Zat protein yang disekresikan mencakup kolagen, suatu serabut putih yang tebal dan berfungsi sebagai penunjang struktural, elastis, protein yang dapat diregangkan yang memungkinkan jaringan melentur sewaktu diregangkan dan serabut retikulum yaitu suatu untaian serabut tipis, fleksibel yang memungkinkan organ mengakomodasi peningkatan volume. Zat serupa gel, sebagian besar terdiri atas asam hialoronat, terdapat berselang seling diseluruh ruangan interstinum untuk mempertahankan air dan berfungsi sebagai penunjang dan pelindung. ${ }^{22}$

Menurut Barrett et al, peregangan perineum dan robekan pada perineum selama proses persalinan dapat melemahkan otot-otot dasar panggul serta 
dinding vagina, trauma pada perineum juga menimbulkan rasa tidak nyaman dan nyeri pada saat melakukan hubungan seksual. ${ }^{23}$ Maka perlunya dilakukan pemijatan perineum pada saat kehamilan.

Berdasarkan penelitian ini dapat dianalisis ternyata ada pengaruh pemijatan perineum pada primigravida terhadap kejadian ruptur perineum saat persalinan antara kelompok intervensi dan kelompok kontrol, karena didaerah perineum terdapat jaringan ikat dan kolagen yang bersifat elastis maka bila dirangsang dengan melakukan pemijatan perineum maka akan terjadi regangan dan kontraksi pada daerah perineum sehingga aliran darah menjadi lancar dan perineum menjadi elastis. ${ }^{24}$

Peregangan pada perineum saat persalinan bisa mengakibatkan perubahan yang positif apabila perineum elastis, fleksible dan lentur maka kejadian ruptur perineum dapat diminimalisir atau tidak terjadi ruptur perineum sama sekali (perineum utuh) dan perubahan yang negatif apabila perineum tidak elastis, fleksible dan lentur maka regangan pada perineum akan mengakibatkan terjadi ruptur perineum. Maka salah satu cara yang dilakukan untuk menghindari terjadinya ruptur perineum dengan melakukan pemijatan perineum. ${ }^{25}$

Hal ini membuktikan manfaat pemijatan perineum yang dapat membantu melunakkan jaringan perineum sehingga jaringan tersebut akan membuka tanpa resistensi pada saat persalinan, untuk mempermudah lewatnya bayi. Pemijatan perineum ini memungkinkan untuk melahirkan bayi dengan perineum tetap utuh. Pemijatan perineum adalah teknik memijat perineum pada waktu hamil atau beberapa minggu sebelum melahirkan guna meningkatkan aliran darah ke daerah ini dan meningkatkan elastisitas perineum. Peningkatan elastisitas perineum akan mencegah kejadian robekan perineum maupun episiotomi. ${ }^{26}$

\section{KESIMPULAN}

Terdapat pengaruh pemijatan perineum pada primigravida terhadap kejadian ruptur perineum dibandingkan dengan kelompok yang tidak dilakukan pemijatan perineum saat persalinan.

\section{UCAPAN TERIMA KASIH}

Penulis mengucapkan terima kasih kepada Dinas Kesehatan Kota Bengkulu atas kesempatan yang diberikan untuk melanjutkan pendidikan. Kepada Bidan Praktek Mandiri di Kota Bengkulu sebagai tempat penelitian atas fasilitas yang telah diberikan. Kepada dr. Ermawati, SpOG(K) dan Elda Yusefni, SST, M.Keb sebagai pembimbing atas masukan dan bimbingan dalam menyelesaikan tesis ini.

\section{DAFTAR PUSTAKA}

1. Manuaba IBG. IImu kebidanan penyakit kandungan \& keluarga berencana untuk pendidikan bidan. Jakarta: EGC; 2010.

2. Departemen Kesehatan. Asuhan persalinan normal. Jakarta; 2008.

3. Herdiana, Trirejeki. Tips pijat perineum. Jakarta: EGC; 2007

4. Oxorn H. Patologi dan fisiologi persalinan. Jakarta: Yayasan Essentia Medika; 2010.

5. Bobak, Lowdermilk. Buku ajar keperawatan maternitas. Jakarta: EGC; 2005.

6. Prawirohardjo S. IImu kebidanan. Jakarta: PT Bina Pustaka Sarwono; 2009.

7. Mochtar R. Sinopsis obstetri. Jakarta: EGC; 2010.

8. Mongan, Marie FM. Hypno birthing: metode melahirkan secara aman, mudah, dan nyaman. Jakarta: BIP; 2007.

9. Sastroasmoro S. Dasar-dasar metodologi penelitian klinis. Jakarta: Sagung Seto; 2011.

10. Hurlock EB. Psikologi perkembangan. Edisi ke-5. Jakarta: Erlangga; 2002.

11. Wiknjosastro $\mathrm{H}$. IImu Kebidanan. Jakarta: Yayasan Bina Pustaka Sarwono Prawirohardjo; 2008. hIm. 72-5.

12. Beckmann MM, Garrett AJ. Antenatal perineal massage for reducing perineal trauma. Cochrane Database of Systematic Reviews, Issue 1. DOI: 10.1002/14651858. CD005123. 2009: 1013-21.

13. Shipman MK, Boniface DR, Tefft ME, McCloghry F. Antenatal perineal massage and subsequent perineal outcomes: a randomised controlled trial. British Journal of Obstetrics and 
Gynaecology.1997;104(7):87-91.

14. Johanson. Vacuum extraction versus forceps for assisted vaginal delivery. Cochrane Database of Systematic Reviews, Issue 2. DOI: 10.1002/14651858.CD000224.1999:345-56.

15. Karazam Z, Ekmen H, Calisir H. The use of perineal masasage in the second stage of labor and follow - up of postpartum perinatal outcame. Health care For Women International, 33. Doi: 10. 1080 /0739332.655385. 2012:697-718.

16. Jones LE, Marsden $\mathrm{N}$. The application of antenatal perineal massage: a review of literature to determine instruction, dosage and technique Journal of the Association of Chartered Physiotherapists in Women's Health, Spring 2008:8-11.

17. Aprilia Y. Rileks nyaman dan aman saat hamil dan melahirkan. Jakarta: Gagas Media; 2010.

18. Chapman. Asuhan kebidanan dan kelahiran. Jakarta: EGC; 2006.
19. Danuatmaja B. Persalinan Normal Tanpa Rasa Sakit. Jakarta: Puspa Swarna; 2004.

20. Cunningham, F. Obstetri Williams. Edisi ke-21. Vol 1. Profitasari, editor edisi bahasa Indonesia. Jakarta: EGC; 2013

21. Chomaria N. Melahirkan Tanpa rasa sakit. Jakarta: Kompas Gramedia; 2012.

22. Corwin, Elizabeth J. Buku saku patofisiologi. Jakarta: EGC; 2009..

23. Barrett G, Albers, Eason. Women's sexual health after childbirth. BJOG: an international journal of obstetrics and gynaecology 2000;107(2):186-95.

24. Melissa D. Perineal massage; effect on the incidence of episiotomy and laceration in nulliparous population. Journal Of Nurse. Midwifery. 2005;32(3):567-77.

25. Andarmoyo S, Suharti. Persalinan tanpa nyeri berlebihan. Jogjakarta: AR-Ruzz Media; 2013.

26. Fraser M, Cooper AM. Myles buku ajar bidan Edisi ke-14. Jakarta: EGC; 2009. 